\title{
PENGARUH PROFESIONALISME, MOTIVASI DAN PENGAWASAN DENGAN KINERJA GURU SMP NEGERI KECAMATAN MAPILLI
}

\author{
Muhammad Alwi \\ Institut Teknologi dan Bisnis Muhammadiyah Polewali Mandar \\ Email: alwibinhamid@gmail.com
}

\begin{abstract}
This research have a purpose (1) to know the existence of influence which [is] Professionalism signifikan with performance learn SMP Country District of Mapilli; (2) to know the existence of influence which [is] signifikan Motivate with performance learn SMP Country District of Mapilli; (3) to know the existence of influence which is observation signifikan with performance learn SMP Country District of Mapilli; and (4) to know the existence of influence with which is signifikan between Professionalism, Motivation, and observation with performance learn SMP Country District of Mapilli. Population in research is teacher of SMP Country exist in District of Mapilli with amount of its population equal to 50 teacher. In this research of sampel the taken is entire/all teacher of SMP Country District of Mapilli, so that this research of meruapakan research of population. Technique analyse data by using Multiple Regression Linear of Analys: Tabulation of data, Assumptions of Multiple Regression and Examination of Hypothesis Research. Result of data analysis is: 1) professionalism level have an effect on postitif to make-up of teacher performance. This matter of indication that high lower him mount professionalism had unidirectional with yielded performance storey;level 2) Motivational level have an effect on postitif to makeup of teacher performance 3) Mount observation have an effect on postitif to make-up of teacher performance. This matter of indication that high lower unidirectional done/conducted observation intensity him with performance storey; level which is yielded. 4) Professionalism, observation and motivation by simultan have an effect on to make-up of teacher performance.
\end{abstract}

Keywords: professionalism, motivation, observation, performance teacher

\section{PENDAHULUAN}

Guru merupakan salah satu komponen yang menempati posisi sentral dan sangat strategi dalam sistem pendidikan. Mulyasa (2009: 5) menyatakan bahwa guru merupakan komponen paling menentukan dalam sistem pendidikan secara keseluruhan, yang harus mendapat perhatian sentral, pertama, dan utama. Bailer (Permadi dan Arifin, 2010: 117) menyatakan bahwa peranan guru dalam proses 
belajar mengajar adalah tempat sangat sentral. Bagaimanapun bagusnya kurikulum, kalau tidak ditunjang oleh kualitas dan kemandirian guru pada akhirnya akan kurang berhasil.

Mengingat begitu pentingnya posisi guru dalam proses belajar mengajar, maka sangatlah wajar apabila fenomena tentang rendahnya kualitas pendidikan akan menunjuk guru sebagai tumpuan kesalahan atau diduga guru sebagai penyebabnya. Oleh karena itu, sudah selayaknyalah profesi guru diperhatikan. Profesi guru harus dibedakan dengan profesi lainnya. Kebijakan yang tidak memihak guru akan berdampak buruk bagi kemajuan bangsa Indonesia (Permadi dan Arifin, 2010: 104).

Salah satu hal yang patut dipertimbangkan adalah bagaimana upaya untuk meningkatkan kualitas guru adalah dengan cara meningkatkan kinerjanya. Kinerja guru yang meningkat akan meningkatkan profesi dan mutunya dengan demikian diharapkan keberhasilan pendidikan akan tercapai.

Kinerja merupakan terjemahan dari kata performance (Job Performance), secara etimologis performance berasal dari kata to perform yang berarti menampilkan atau melaksanakan. Menurut Mulyasa (2009: 88) kinerja adalah unjuk kerja seseorang yang ditunjukkan dalam penampilan, perbuatan, dan prestasi kerjanya sebagai akumulasi dari pengetahuan, keterampilan, nilai dan sikap yang telah dimilikinya. Tugas pokok guru yang diwujudkan dalam kegiatan belajar mengajar merupakan bentuk kinerja guru. Kinerja guru dapat dilihat saat dia melaksanakan interaksi belajar mengajar di kelas termasuk persiapannya baik dalam bentuk program semester maupun persiapan mengajar.

Profesonalisme guru merupakan karakter seorang guru dalam menjalankan aktivitas sebagai seorang pengajar dan pendidik secara utuh dan bertanggungjawab. Dalam pelaksanaannya guru professional adalah guru yang ingin mengedepankan mutu dan kualitas layanan dan produknya, layanan guru harus memenuhi standarisasi kebutuhan masyarakat, bangsa dan pengguna serta memaksimalkan kemampuan peserta didik berdasar potensi dan kecakapan yang dimiliki masing-masing individu.

Penilaian seorang guru profesional dapat dilakukan dengan meninjau pada beberapa hal, antara lain: penguasaaan pada kurikulum, penguasaan materi pelajaran yang diemban, penguasaan pada metode evaluasi belajar dan sikapnya terhadap tugas, sehingga akan mampu meningkatkan kinerja guru tersebut yang pada akhirnya dapat meningkatkan hasil belajar peserta didik. Sedangkan kinerja itu sendiri dapat diukur dari rencana pengajaran yang dilakukan serta bagaimana pelaksanaan pengajarannya. Dengan demikian makin baik tingkat penguasaan kurikulum, materi pelajaran yang diemban, metode dan evaluasi pelajaran dan sikapnya terhadap tugas yang dimiliki, makin baik pula kinerja yang dihasilkan.

Motivasi dapat diartikan sebagai dorongan yang dimiliki sebagai stimulus dalam bekerja guna mencapai tujuan yang diharapan. Adapaun motivasi kerja 
guru adalah kondisi yang membuat guru mempunyai kemauan/kebutuhan untuk mencapai tujuan tertentu melalui pelaksanaan suatu tugas. Motivasi kerja guru akan mensuplai energi untuk bekerja / mengarahkan aktivitas selama bekerja, dan menyebabkan seorang guru mengetahui adanya tujuan yang relevan antara tujuan organisasi dengan tujuan pribadinya.

Sementara untuk menilai motivasi guru tersebut dapat dilakukan dengan meninjau pada sikap bangga terhadap pekerjaannya, perilaku yang menunjukkan kebutuhan akan prestasi dan peluang untuk berkembang, kebutuhan akan pengakuan serta tingkat kompensasi (gaji) yang diterima. Beberapa tinjauan tersebut terkait dorongan baik dari sisi intrinsik maupun sisi ekstrinsik seorang guru.

Dorangan untuk memaksimalkan proses pembelajaran yang dilakukan baik dorongan dari dalam diri (instrinsik) maupun dorongan yang bersumber dari luar diri (ekstrinsik) oleh guru merupakan faktor penting untuk mencapai tujuan yang diharapan, dalam hal ini adalah kinerja yang baik sebagai seorang guru. Dengan meningkatnya motivasi yang dimiliki oleh guru maka tentu akan memicu guru tersebut untuk melaksanakan tugas dengan baik yang pada akhirnya akan membuat kinerja yang dihasilkan juga baik.

Pengawasan pada dasarnya merupakan aktifitas yang dilakukan didalam suatu kegiatan untuk menghindari adanya kemungkinan penyelewengan atau penyimpangan atas tujuan yang akan dicapai. Melalui pengawasan diharapkan dapat membantu melaksanakan kebijakan yang telah ditetapkan untuk mencapai tujuan yang telah direncanakan secara efektif dan efisien serta mampu mencipakan suatu aktivitas yang berkaitan erat dengan penentuan atau evaluasi mengenai sejauhmana pelaksanaan kerja sudah dilaksanakan.

Pada pelaksanaannya pengawasan dilakukan dalam bentuk pengawasan awal kegiatan (feedforward), pelaksanaan yang dilakukan saat berlangsungnya kegiatan (concurrent) dan pelaksanaan yang dilakukan diakhir kegiatan (feedback). Ketiga bentuk pengawasan ini akan mampu mengindikasi jika terjadi suatu penyimpangan didalam melaksanakan suatu aktifitas atau kegiatan, dalam hal ini adalah proses berlangsungnya kegiatan atau aktifitas pembelajaran yang dilakukan oleh guru. Oleh karena itu intensitas pengawasan yang dilakukan akan berdampak pada kinerja guru, oleh karena kinerja berkaitan erat dengan pelaksanaan pembelajaran dan evaluasi yang dilakukan.

Kinerja merupakan prestasi kerja yang dicapai seseorang dalam melaksanakan tugas-tugas yang dibebankan kepadanya didasarkan atas kecakapan, pengalaman dan kesungguhan serta waktu. Sementara kinerja guru dapat didefinisikan sebagai persepsi guru terhadap prestasi kerja guru yang berkaitan dengan kualitas kerja, tanggung jawab, kejujuran, kerjasama dan prakarsa yang dapat diukur melalui kecenderungan pada rencana pengajaran, pelaksanaan pengajaran, hubungan antar pribadi dan evaluasi yang dimiliki. 
Sikap profesional seorang guru berhubungan dengan tingkat penguasaan kurikulum, materi pelajaran yang diemban, metode dan evaluasi pelajaran dan sikapnya terhadap tugas yang dimiliki didugan akan memberikan kontribusi posistif pada kinerja yang dihasilkan. Sementara motivasi yang dimiliki oleh guru maka tentu akan memicu guru tersebut untuk melaksanakan tugas dengan baik yang pada akhirnya akan membuat kinerja yang dihasilkan juga baik. Adapun intensitas pengawasan yang dilakukan akan berdampak pada kinerja guru, oleh karena kinerja berkaitan erat dengan pelaksanaan pembelajaran dan evaluasi yang dilakukan.

\section{METODE PENELITIAN}

Penelitian ini merupakan penelitian deskriptif yang mengkaji secara lugas pengaruh profesionalisme, motivasi dan pengawasan terhadap kinerja guru. Dalam kegiatan penelitian, peneliti memotret apa yang terjadi pada diri objek atau wilayah yang diteliti, kemudian memaparkan apa yang terjadi dalam bentuk laporan penelitian secara lugas, seperti apa adanya (Arikunto, 2010:3).

Berdasarkan tujuan, pendekatan yang digunakan adalah kuantitatif, karena data penelitian yang dihasilkan berupa angka-angka untuk kemudian dianalisis menggunakan statistik (Sugiyono, 2012:7).

Dalam penelitian ini objek yang menjadi variabel dalam penelitian didasari oleh kriteria tingkat profesionalisme, motivasi, pengawasan dan kinerja guru. Adapun desain penelitiannya seperti pada gambar 1 berikut.

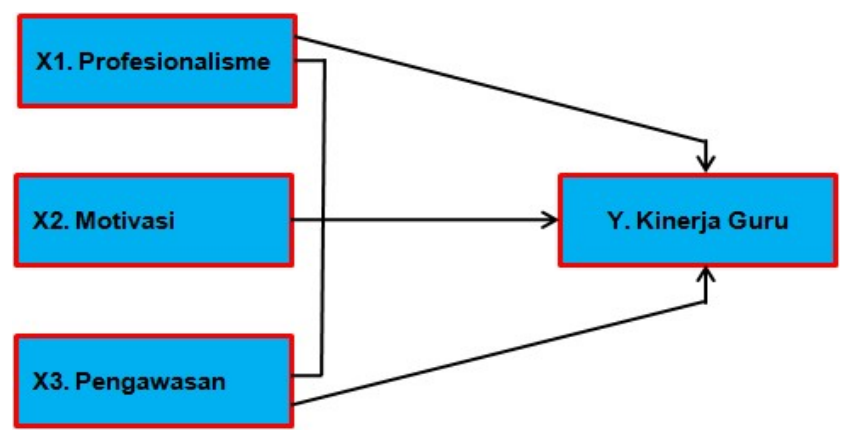

Gambar 1. Desain Penelitian

Populasi dalam penelitian ini adalah seluruh guru SMP Negeri di Kecamatan Mapilli dari 3 SMP Negeri yang jumlahnya 50 orang.

Teknik pengumpulan data yang digunakan dalam penelitian ini yaitu: 
Observasi

Observasi dilakukan dilokasi penelitian untuk keperluan studi pendahuluan dengan melihat dan mengamati secara acak dan langsung keadaan sekolah dan situasi pengajaran yang dilakukan oleh para guru.

\section{Dokumentasi}

Teknik pengumpulan data penelitian dengan menggunakan dokumentasi adalah teknik pengumpulan data berdasarkan sumber tulisan atau tertulis dimana pada metode pelaksanaannya dapat digunakan untuk memuat kategori data yang akan dicari (Arikunto, 2010:201). Pada penelitian ini metode dokumentasi digunakan untuk memperoleh data sekunder berupa: (1) jumlah guru SMP Negeri yang ada di Kecamatan Mapilli, (2) jumlah SMP Negeri di Kecamatan Mapilli dan (3) alamat SMP Negeri di Kecamatan Mapilli.

\section{Angket (kuesioner)}

Kuesioner, yaitu teknik pengumpulan data yang dilakukan dengan cara memberikan sejumlah pertanyaan tertulis secara terstruktur kepada responden penelitian berkaitan dengan tanggapannya terhadap berbagai variabel yang diteliti dalam penelitian ini.

\section{Wawancara (interview)}

Wawancara, yaitu pengumpulan data sebagai penguatan dari jawaban kuesioner yang telah dibagikan sebelumnya. Wawancara merupakan pertemuan dua orang untuk bertukar informasi dan ide melalui tanya jawab, sehingga dapat dikontruksikan makna dalam suatu topik tertentu (Sugiyono, 2012:231). Teknik wawancara dalam penelitian ini digunakan untuk mengetahui hal-hal dari responden yang lebih mendalam sehubungan dengan bagaimana kelengkapan dan pemanfaatan alat dalam proses pembelajaran gambar teknik. Dengan demikian pengumpulan data dengan teknik wawancara berfungsi sebagai penguatan dari jawaban kuesioner yang telah dibagikan sebelumnya.

\section{Sumber Data}

Sumber data adalah subjek dari mana data dapat diperoleh (Arikunto, 2010:172). Berdasarkan tujuan penelitian maka sumber data untuk pengambilan data yang dibutuhkan adalah dari pihak sekolah dan guru-guru SMP Negeri di kecamatan Mapilli selaku responden penelitian. Adapun jenis data, sumber data dan cara pengambilan data secara rinci dapat dilihat pada tabel 1 berikut.

Tabel 1. Jenis, sumber dan cara pengambilan data.

\begin{tabular}{|c|c|c|c|}
\hline No. & $\begin{array}{c}\text { Jenis } \\
\text { Kebutuhan Data }\end{array}$ & $\begin{array}{c}\text { Sumber } \\
\text { Perolehan Data }\end{array}$ & $\begin{array}{c}\text { Cara } \\
\text { Pengumpulan Data }\end{array}$ \\
\hline A. & Data Primer: & & \\
\hline & 1. Profesionalisme guru & $\begin{array}{l}\text { Guru SMP Negeri di } \\
\text { Kecamatan Mapilli }\end{array}$ & $\begin{array}{ll}- & \text { Kuesioner } \\
\text { - } & \text { Wawancara } \\
\end{array}$ \\
\hline & 2. Motivasi guru & Guru SMP Negeri di & $\begin{array}{ll}- & \text { Kuesioner } \\
\end{array}$ \\
\hline
\end{tabular}




\begin{tabular}{|l|l|l|ll|}
\hline & & Kecamatan Mapilli & - & Wawancara \\
\hline & $3 . \quad$ Pengawasan guru & $\begin{array}{l}\text { Guru SMP Negeri di } \\
\text { Kecamatan Mapilli }\end{array}$ & $\begin{array}{l}\text { Kuesioner } \\
-\end{array}$ \\
\hline & Wawancara \\
\hline B. & Data Sekunder: & $\begin{array}{l}\text { Guru SMP Negeri di } \\
\text { Kecamatan Mapilli }\end{array}$ & $\begin{array}{l}\text { Kuesioner } \\
\text { Wawancara }\end{array}$ \\
\hline & $\begin{array}{l}\text { 1. Jumlah Guru tiap } \\
\text { SMP Negeri di }\end{array}$ & $\begin{array}{l}\text { Stakeholder SMP } \\
\text { Negeri di Kecamatan } \\
\text { Mapilli }\end{array}$ & - & $\begin{array}{l}\text { Oburvey sekolah } \\
\text { lapangan }\end{array}$ \\
\hline & $\begin{array}{l}\text { Jumlah SMP Negeri } \\
\text { di Kecamatan Mapilli }\end{array}$ & $\begin{array}{l}\text { Stakeholder SMP } \\
\text { Negeri di Kecamatan } \\
\text { Mapilli }\end{array}$ & - & $\begin{array}{l}\text { Survey sekolah } \\
\text { Observasi } \\
\text { lapangan }\end{array}$ \\
\hline & $\begin{array}{l}\text { Alamat SMP Negeri } \\
\text { di Kecamatan Mapilli }\end{array}$ & $\begin{array}{l}\text { Stakeholder SMP } \\
\text { Negeri di Kecamatan } \\
\text { Mapilli }\end{array}$ & - & $\begin{array}{l}\text { Survey sekolah } \\
\text { Observasi } \\
\text { lapangan }\end{array}$ \\
\hline
\end{tabular}

\section{Kisi-Kisi Instrumen Penelitian}

Instrumen penelitian adalah alat ukur di dalam penelitian yang digunakan untuk mengukur fenomena alam maupun sosial yang diamati. Secara spesifik semua fenomena ini disebut variabel penelitian (Sugiyono, 2012:102). Berdasarkan teknik pengumpulan data yang digunakan maka instrumen yang digunakan dalam penelitian ini berupa angket tertutup dengan mengggunakan skala Likert.

\section{HASIL DAN PEMBAHASAN}

Data yang disajikan dalam bagian ini meliputi data: (1) variabel profesionalisme $(\mathrm{X} 1),(2)$ variabel motivasi $(\mathrm{X} 2),(3)$ variabel pengawasan (X3) dan variabel kinerja guru (Y). Selain itu data juga disajikan berdasarkan indikator-indikator pada tiap variabel tersebut. Adapun gambaran setiap variabel secara berurutan dijabarkan sebagai berikut:

\section{a. Profesionalisme Guru (X1)}

Profesionalisme guru yang ingin diketahui mengacu pada indikatorindikator yang telah ditetapkan, meliputi: (1) penguasaan kurikulum, (2) penguasaan materi pelajaran, (3) penguasaan metode dan evaluasi belajar, (4) penyikapan terhadap tugas guru, yang dimiliki untuk memaksimalkan kemampuan peserta didik berdasar potensi dan kecakapan yang dimiliki masingmasing individu. Hasil analisis dari setiap indikator profesionalisme sebagai berikut.

\section{(1) Penguasaan Kurikulum (X1.a)}

Secara kumulatif Guru SMP Negeri di Kecamatan Mapilli memiliki penguasaan kurikulum yang baik. Adapun hasil identifikasi penguasaan kurikulum berdasarkan perolehan skor rata-rata tiap responden (guru) diketahui 
sebesar 38\% (19 dari 50 responden) yang memiliki penguasaan kurikulum yang sangat baik, sebesar $62 \%$ (31 dari 50 responden) yang memiliki penguasaan kurikulum dalam kategori baik dan tidak terdapat guru dengan penguasaan kurikulum yang termasuk pada kategori cukup, tidak baik atau bahkan sangat tidak baik $(0 \%)$. Dengan demikian mayoritas penguasaan kurikulum oleh guru dalam penelitian ini berada dalam kategori baik dengan persentase sebesar $62 \%$.

\section{(2) Penguasaan Materi Mata Pelajaran (X1.b)}

Hasil analisis perolehan skor rata-rata tiap responden (guru) menunjukkan bahwa pada penguasaan materi pelajaran terdapat sebesar 38\% (19 dari 50 responden) memiliki penguasaan materi pelajaran dalam kategori sangat baik, sebesar 56\% (28 dari 50 responden) dalam kategori baik, sebesar 6\% (3 dari 50 responden) dalam kategori cukup baik dan tidak terdapat responden (guru) yang teridentifikasi termasuk dalam kategori tidak baik dan atau sangat tidak baik $(0 \%)$. Berdasarkan penjabaran tersebut maka identifikasi penguasaan materi pelajaran didominasi oleh kategori baik dengan persentase sebesar 56\%.

(3) Penguasaan Metode dan Evaluasi Belajar (X1.c)

Hasil analisis perolehan skor rata-rata tiap responden (guru) menunjukkan bahwa pada penguasaan metode dan evaluasi belajar terdapat sebesar 36\% (18 dari 50 responden) yang memiliki penguasaan metode dan evaluasi belajar dalam kategori sangat baik, sebesar $62 \%$ (31 dari 50 responden) dalam kategori baik, $2 \%$ (1 dari 50 responden) dalam kategori cukup baik dan tidak terdapat responden dengan kecenderungan pada kategori tidak baik dan sangat tidak baik $(0 \%)$. Penjabaran tersebut menunjukkan bahwa metode dan evaluasi belajar oleh guru didominasi oleh kategori baik dengan persentase sebesar $62 \%$.

(4) Penyikapan Terhadap Tugas (X1.d)

Hasil analisis perolehan skor rata-rata tiap responden (guru) menunjukkan bahwa terdapat sebesar $42 \%$ (21 dari 50 responden) menyikapi tugas sebagai guru dengan sangat baik, sebesar 58\% (29 dari 50 responden) memberikan penyikapan terhadap tugas guru termasuk dalam kategori baik dan tidak teridentifikasi guru dalam menyikapi tugasnya dengan kategori cukup, tidak baik atau bahkan sangat tidak baik $(0 \%)$. Dengan demikian mayoritas menyikapi tugasnya sebagai seorang guru dengan kategori baik dengan persentase sebesar $58 \%$.

\section{Motivasi (X2)}

Motivasi guru yang ingin diketahui mengacu pada indikator-indikator yang telah ditetapkan, meliputi: (1) kebutuhan akan prestasi, (2) kebutuhan untuk berkembang, (3) kebangggan terhadap pekerjaan, (4) kebutuhan akan pengakuan dan (5) kompensasi (gaji) yang diterima, yang dimiliki sehingga dapat menimbulkan semangat atau dorongan bekerja individu atau kelompok terhadap profesinya sebagai tenaga pendidik guna mencapai tujuan tertentu melalui pelaksanaan suatu tugas. Penjabaran hasil statistik setiap indikator motivasi guru dijabarkan sebagai berikut. 


\section{1) Kebutuhan Akan Prestasi (X2.a)}

Hasil analisis perolehan skor rata-rata tiap responden (guru) menunjukkan bahwa terdapat sebesar 50\% (25 dari 50 responden) menunjukkan sikap terkait kebutuhan akan prestasi dalam kategori sangat baik, sebesar 48\% (24 dari 50 responden) dalam kategori baik, sebesar 2\% (1 dari 50 responden) dalam kategori cukup baik dan tidak ditemukan kecenderungan dalam kategori tidak baik dan sangat tidak baik $(0 \%)$. Penjabaran tersebut menunjukkan bahwa sikap guru terkait kebutuhan akan prestasi didominasi oleh kategori sangat baik dengan persentase sebesar $50 \%$.

\section{2) Kebutuhan Untuk Berkembang (X2.b)}

Hasil analisis perolehan skor rata-rata tiap responden (guru) menunjukkan bahwa terdapat sebesar 54\% (27 dari 50 responden) menunjukkan sikap terkait kebutuhan untuk berkembang dalam kategori sangat baik, sebesar 38\% (19 dari 50 responden) dalam kategori baik, sebesar 8\% (4 dari 50 responden) dalam kategori cukup baik dan tidak ditemukan kecenderungan dalam kategori tidak baik dan sangat tidak baik $(0 \%)$. Temuan tersebut menunjukkan bahwa sikap guru terkait kebutuhan untuk berkembang didominasi oleh kategori sangat baik dengan persentase sebesar $54 \%$.

\section{3) Kebanggaan Terhadap Pekerjaan (X2.c)}

Adapun hasil analisis perolehan skor rata-rata tiap responden (guru) menunjukkan bahwa terdapat sebesar 46\% (23 dari 50 responden) menunjukkan sikap bangga terhadap pekerjaan dalam kategori sangat baik, sebesar 50\% (25 dari 50 responden) dalam kategori baik, sebesar 4\% (2 dari 50 responden) dalam kategori cukup baik dan tidak ditemukan kecenderungan dalam kategori tidak baik dan sangat tidak baik $(0 \%)$. Temuan tersebut menunjukkan bahwa sikap bangga guru terhadap pekerjaan didominasi oleh kategori baik dengan persentase sebesar $50 \%$.

\section{4) Kebutuhan Akan Pengakuan (X2.d)}

Adapun hasil analisis perolehan skor rata-rata tiap responden (guru) menunjukkan bahwa terdapat sebesar 46\% (23 dari 50 responden) menunjukkan sikap kebutuhan akan pengakuan dalam kategori sangat baik, sebesar 52\% (26 dari 50 responden) dalam kategori baik, sebesar 2\% (1 dari 50 responden) dalam kategori cukup baik dan tidak ditemukan kecenderungan dalam kategori tidak baik dan sangat tidak baik $(0 \%)$. Temuan tersebut menunjukkan bahwa sikap kebutuhan akan pengakuan didominasi oleh kategori baik dengan persentase sebesar $52 \%$.

\section{5) Kompensasi (Gaji) yang Diterima (X2.e)}

Adapun hasil analisis perolehan skor rata-rata tiap responden (guru) menunjukkan bahwa terdapat sebesar 44\% (22 dari 50 responden) menunjukkan sikap terhadap tingkat gaji yang dterima dalam kategori sangat baik, sebesar $44 \%$ (22 dari 50 responden) dalam kategori baik, sebesar 12\% (6 dari 50 responden) 
dalam kategori cukup baik dan tidak ditemukan kecenderungan dalam kategori tidak baik dan sangat tidak baik $(0 \%)$. Berdasarkan beberapa temuan tersebut menunjukkan bahwa sikap guru terhadap tingkat gaji yang diterima didominasi oleh kategori sangat baik dan kategori baik dengan persentase sebesar $44 \%$.

\section{Pengawasan Guru (X3)}

Pengawasan guru yang ingin diketahui mengacu pada indikator-indikator yang telah ditetapkan, meliputi: (1) pengawasan feedforward, (2) pengawasan concurrent dan (3) pengawasan feedback yang dilakukan sehingga dapat menghindari adanya kemungkinan penyelewengan atau penyimpangan atas tujuan yang akan dicapai. Hasil statistik setiap indikator pengawasan guru dijabarkan sebagai berikut.

\section{1) Pengawasan Feedforward (X3.a)}

Hasil analisis perolehan skor rata-rata tiap responden (guru) menunjukkan bahwa terdapat sebesar $48 \%$ (24 dari 50 responden) melakukan kegiatan pengawasan feedforward dengan sangat baik, sebesar 50\% (25 dari 50 responden) termasuk dalam kategori baik, 2\% (1 dari 50 responden) dalam kategori cukup baik dan tidak ditemukan kecenderungan dalam kategori tidak baik dan sangat tidak baik $(0 \%)$. Bertolak pada beberapa temuan tersebut menunjukkan bahwa kegiatan pengawasan feedforward oleh guru didominasi oleh kategori baik dengan persentase sebesar $50 \%$.

\section{2) Pengawasan Concurrent (X3.b)}

Identifikasi pada perolehan skor rata-rata tiap responden (guru) menunjukkan bahwa terdapat sebesar 48\% (24 dari 50 responden) melakukan kegiatan pengawasan concurrent dengan sangat baik, sebesar 50\% (25 dari 50 responden) termasuk dalam kategori baik, 2\% (1 dari 50 responden) dalam kategori cukup baik dan tidak ditemukan kecenderungan dalam kategori tidak baik dan sangat tidak baik $(0 \%)$. Dengan demikian mayoritas kegiatan pengawasan concurrent oleh guru didominasi oleh kategori baik dengan persentase sebesar $50 \%$.

\section{3) Pengawasan Feedback (X3.e)}

Hasil identifikasi pada perolehan skor rata-rata tiap responden (guru) menunjukkan bahwa terdapat sebesar 58\% (29 dari 50 responden) melakukan kegiatan pengawasan feedcak dengan sangat baik, sebesar 38\% (19 dari 50 responden) termasuk dalam kategori baik, 4\% (2 dari 50 responden) dalam kategori cukup baik dan tidak ditemukan kecenderungan dalam kategori tidak baik dan sangat tidak baik $(0 \%)$.

Dengan demikian mayoritas kegiatan pengawasan feedback oleh guru didominasi oleh kategori sangat baik dengan persentase sebesar $58 \%$. 


\section{Kinerja Guru (Y)}

Kinerja guru yang ingin diketahui mengacu pada indikator-indikator yang telah ditetapkan, meliputi: (1) rencana pengajaran, (2) pelaksanaan pengajaran, (3) hubungan antar pribadi dan (4) pelaksanaan evaluasi yang dilakukan sehingga dapat diketahui prestasi kerja guru yang berkaitan dengan upaya peningkatan kualitas pembelajaran yang dilakukan. Penjabaran hasil statistik setiap indikator kinerja guru disajikan sebagai berikut.

\section{1) Rencana Pengajaran $\left(Y_{a}\right)$}

Mengacu pada identifikasi perolehan skor rata-rata tiap responden (guru) dikatehui pula bahwa terdapat sebesar $48 \%$ (24 dari 50 responden) melakukan rencana pengajaran dengan sangat baik, sebesar 52\% (26 dari 50 responden) termasuk dalam kategori baik dan dan tidak ditemukan kecenderungan dalam kategori cukup baik, tidak baik dan atau sangat tidak baik $(0 \%)$. Temuan tersebut menunjukkan bahwa rencana pengajaran yang dilakukan oleh responden (guru) didominasi oleh kategori baik dengan persentase sebesar $52 \%$.

\section{2) Pelaksanaan Pengajaran $\left(\mathbf{Y}_{\mathbf{b}}\right)$}

Mengacu pada identifikasi perolehan skor rata-rata tiap responden (guru) dikatehui pula bahwa terdapat sebesar 46\% (23 dari 50 responden) melaksanakan pengajaran dengan sangat baik, sebesar 48\% (24 dari 50 responden) termasuk dalam kategori baik, sebesar 6\% (3 dari 50 responden) dalam kategori cukup baik dan tidak ditemukan kecenderungan dalam tidak baik dan sangat tidak baik $(0 \%)$. Dengan demikian mayoritas guru dalam melaksanakan pengajaran didominasi oleh kategori baik.

\section{3) Hubungan Antar Pribadi $\left(\mathbf{Y}_{\mathbf{c}}\right)$}

Identifikasi perolehan skor rata-rata tiap responden (guru) dikatehui bahwa terdapat sebesar 32\% (16 dari 50 responden) memiliki hubungan antar pribadi yang sangat baik, sebesar $60 \%$ (30 dari 50 responden) termasuk dalam kategori baik, sebesar 8\% (4 dari 50 responden) dalam kategori cukup baik dan tidak ditemukan kecenderungan dalam tidak baik dan sangat tidak baik $(0 \%)$. Temuan tersebut menunjukkan bahwa penilaian hubungan antar pribadi didominasi oleh kategori baik dengan persentase sebesar $60 \%$.

\section{4) Pelaksanaan Kegiatan Evaluasi $\left(\mathbf{Y}_{d}\right)$}

Hasil identifikasi perolehan skor rata-rata tiap responden (guru) dikatehui bahwa terdapat sebesar 42\% (21 dari 50 responden) melaksanakan kegiatan evaluasi dengan sangat baik, sebesar 54\% (27 dari 50 responden) termasuk dalam kategori baik, sebesar 4\% (2 dari 50 responden) dalam kategori cukup baik dan tidak ditemukan kecenderungan dalam kategori tidak baik dan sangat tidak baik $(0 \%)$. Temuan tersebut menunjukkan bahwa pelaksanaan kegiatan evaluasi didominasi oleh kategori baik dengan persentase sebesar $54 \%$. 


\section{Hubungan Antar Variabel}

Secara utuh hubungan antar variabel dijelaskan pada gambar 2 berikut.

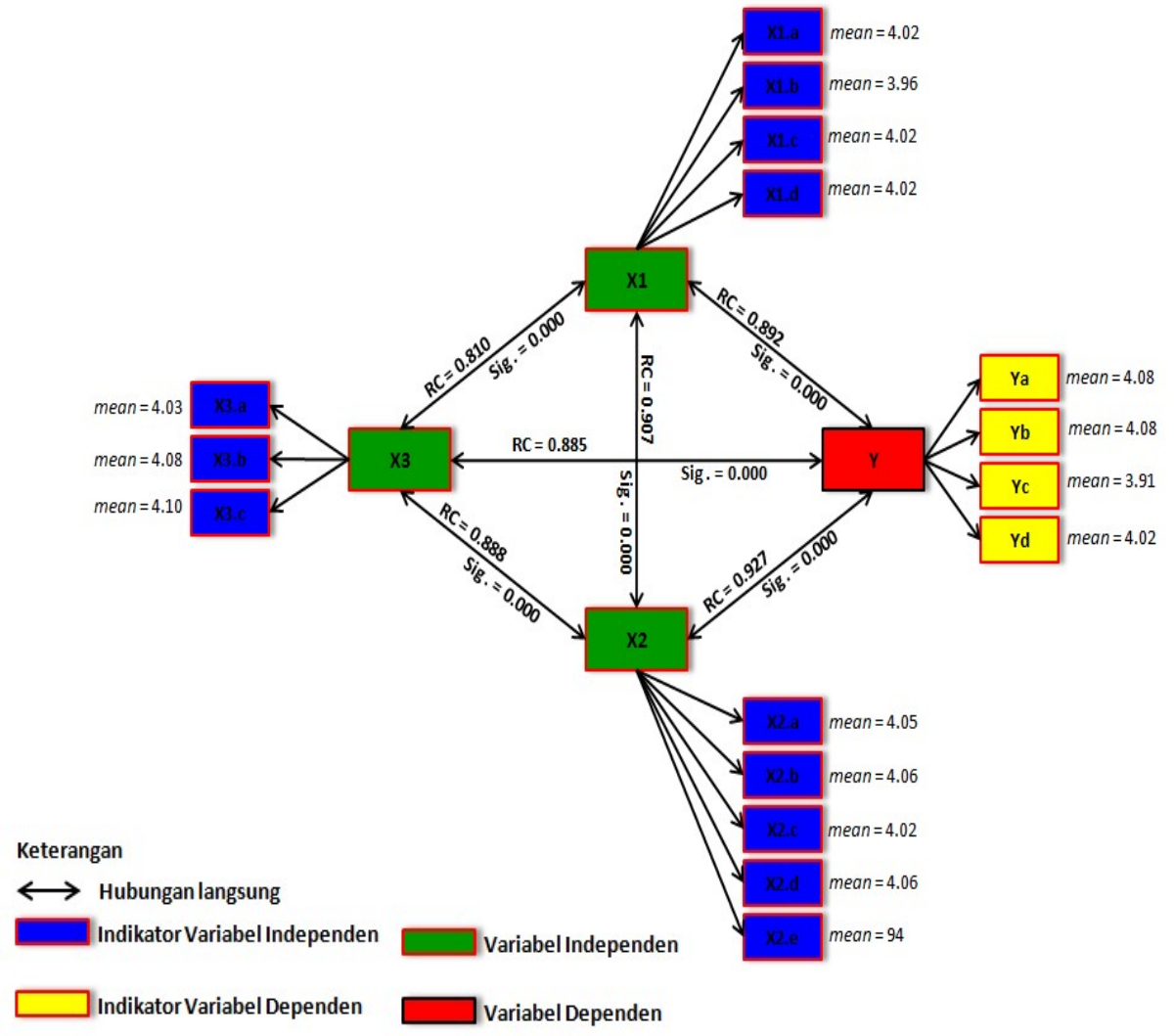

Gambar 2. Skema hasil pengujian secara utuh dan nilai korelasi antara variabel profesionalisme, motivasi, pengawasan dan kinerja guru SMP Negeri di Kecamatan Mapilli

\section{Hubungan Antara Variabel Independen dan Dependen dengan Indikatornya}

hubungan antara variabel independen dengan variabel dependen, hubungan antara variabel independen dengan indikatornya dan hubungan antara variabel dependen dengan indikatornya dapat dilihat pada gambar 3 berikut. 


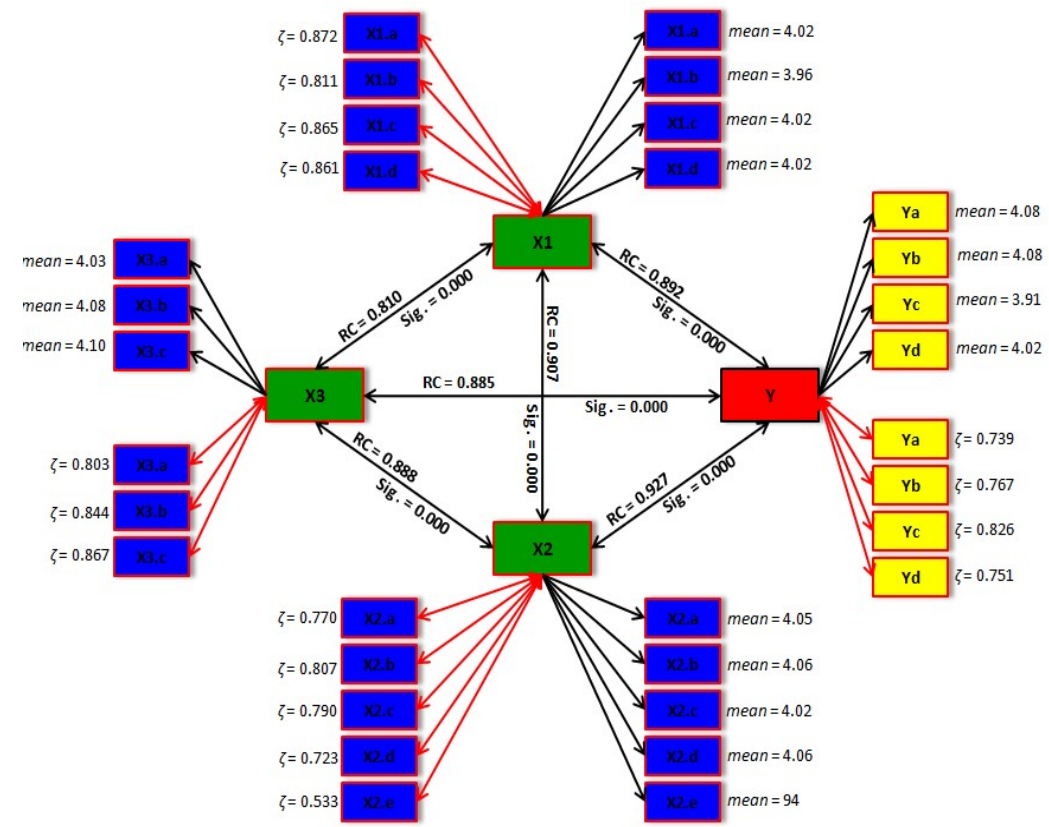

Keterangan

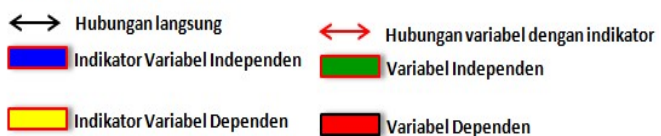

Gambar 3. Skema hasil pengujian secara utuh dan nilai korelasi antara variabel independen dengan variabel dependen, variabel independen dengan indikatornya dan variabel dependen dengan indikatornya

Pada bagian ini berisi tentang pejelasan mendalam dan logis atas buktibukti empirik yang telah ditemukan. Pembahasan didukung oleh teori-teori yang relevan guna memperkuat hasil temuan penelitian ini.

\section{Pengaruh Profesionalisme terhadap Kinerja Guru}

Berdasarkan temuan yang diuraikan pada bagian hasil penelitian, diperoleh bukti empirik bahwa profesionalisme guru berpengaruh terhadap kinerja guru. Besarnya koefisien pengaruh langsung profesionalisme terhadap kinerja guru bertanda positif $(0.313)$. Hal ini mengindikasikan bahwa pengaruh profesionalisme terhadap kinerja guru adalah positif, atau dengan kata lain memiliki arah yang searah. Artinya, semakin tinggi tingkat profesionalisme seorang guru maka akan semakin meningkatkan kinerja guru tersebut. Begitu pula sebaliknya semakin menurun profesionalisme seorang guru maka akan membuat kinerjanya semakin rendah. 
Temuan ini relevan dengan hasil penelitian Dewi (2013) yang menyimpulkan bahwa profesionalisme guru berpengaruh signifikan terhadap kinerja guru. Hal ini mengisyaratkan akan pentingnya profesionalisme guru sebagai upaya dalam meningkatkan kualitas pembelajaran. Profesionalisme seorang guru begitu penting di dalam dunia pendidikan. Di dalam dunia pendidikan, guru adalah seorang pendidik, pembimbing, pelatih, dan pengembang kurikulum yang dapat menciptakan kondisi dan suasana belajar yang kondusif, yaitu suasana belajar menyenangkan, menarik memberi rasa aman, memberikan ruang pada siswa untuk berpikir aktif, kreatif, dan inovatif dalam mengeksplorasi dan mengelaborasi kemampuannya.

Berdasarkan hasil analisis deskriptif ditemukan butkti empirik bahwa tingkat profesionalisme Guru SMP Negeri di Kecamatan Mapilli termasuk pada kategori tinggi. Meskipun demikian terdapat beberapa kekurangan yang ditemui. Beberapa kekurangan yang dimaksud adalah masih terdapat beberapa guru yang belum memiliki penguasaan terhadap materi pelajaran dengan baik dan beberapa guru masih belum memiliki penguasaan terhadap metode dan evaluasi pengajaran yang dilakukan.

Beberapa kekurangan tersebut perlu mendapat perhatian lebih oleh karena salah satu indikator yang menjadikan seorang guru profesional dalam menjalankan aktifitasnya sebagai seorang pengajar dan pendidik perlu menguasai materi yang akan diajarkan serta metode yang digunakan. Sehingga dapat menunjang kemampuan dan atau pengetahuan anak didik yang kemudian akan meningkatkan kualitas pembelajaran. Asumsi ini diperkuat oleh adanya bukti dalam penelitian bahwa terdapat hubungan yang sangat kuat antara profesionalisme guru baik dengan penguasaan materi pembelajaran maupun dengan penguasaan metode dan evaluasi belajar.

\section{Pengaruh Motivasi terhadap Kinerja Guru}

Berdasarkan hasil analisis regresi telah dilakukan pada bagian analisis data diketahui bahwa motivasi guru berpengaruh terhadap kinerja guru. Besarnya koefisien pengaruh langsung motivasi terhadap kinerja guru bertanda positif (0.481). Hal ini mengindikasikan bahwa pengaruh motivasi terhadap kinerja guru adalah positif yakni memiliki arah yang sama. Artinya, semakin tinggi motivasi seorang guru maka akan semakin meningkatkan kinerja guru tersebut. Demikian pula semakin menurunnya motivasi guru akan mebuat kinerjanya semakin rendah.

Hasil temuan ini didukung oleh hasil penelitian Dewi (2013) yang membuktikan bahwa terdapat pengaruh positif antara motivasi terhadap kinerja guru, meskipun pengaruh yang diberikan kecil. pengaruh motivasi sangat besar untuk meningkatkan kinerja guru dalam melaksanakan tugasnya sebagai pengajar sekaligus sebagai seorang pendidik. Kedua temuan ini memperkuat bukti bahwa terdapat pengaruh nyata antara motivasi guru terhadap kinerja yang 
dihasilkan.Rumusan tersebut juga diperkuat dengan bukti yang diperoleh di dalam analisis penilitian bahwa antara motivasi dengan kinerja guru memiliki hubungan yang sangat kuat.

Menurut Malayu (2005: 143), motivasi berasal dari kata latin movere yang berarti dorongan atau pemberian daya penggerak yang menciptakan kegairahan kerja seseorang agar mereka mau bekerja sama, bekerja efektif, dan terintegrasi dengan segala daya upayanya untuk mencapai kepuasan. Oleh karena itu motivasi merupakan hal yang menyebabkan, menyalurkan, dan mendukung prilaku manusia, supaya mau bekerja giat dan antusias mencapai hasil yang optimal.

Analisis statistik deskriptif yang yang telah dilakukan di dalam penelitian ini menunjukkan bahwa tingkat motivasi guru SMP Negeri di Kecamatan Mapilli termasuk pada kategori tinggi. Meskipun demikian masih terdapat beberapa hal yang perlu mendapat perhatian diantaranya adalah sikap seorang guru yang menunjukkan kurangnya rasa bangga terhadap pekerjaannya, hal ini diidentifikasi karena sebagian guru yang menjadi responden didalam penelitian kurang memiliki rasa percaya diri dalam melaksanakan tugasnya sebagai guru. Berdasarkan wawancara mendalam yang dilakukan diketahui beberapa guru menyatakan bahwa penguasaaannya kepada materi yang diajarkan belum mencukupi.

Selain itu pula ditemukan terdapat beberapa guru yang menunjukkan sikap yang perlu mendapat perhatian oleh karena belum menunjukkan sikap dan perilaku yang membuat profesi guru sebagai suatu kebutuhan untuk berkembang. Sementara telah dibuktikan bahwa antara motivasi dengan sikap yang menunjukkan kebutuhan untuk berkembang memiliki hubungan yang kuat. Hal ini teridentifikasi karena masih terdapat beberapa guru yang kurang merepon pada pengembangan metode-metode baru dalam proses pembelajaran karena menganggap jika dengan metode yang telah digunakan sudah cukup untuk keperluan proses pembelajaran maka tidak perlu lagi untuk bersusah payah melakukan eksplorasi pada metode-metode pembelajaran yang baru.

Oleh karena telah terbukti secara empirik bahwa antara motivasi terhadap kinerja guru memliki pengaruh dan hubungan nyata atau signifikan maka sudah barang tentu diperlukan pengembangan dan atau eksplorasi untuk menjaga dan meningkatkan motivasi sebagai upaya untuk mengptimalkan kualitas pembelajran.

\section{Pengaruh Pengawasan Terhadap Kinerja Guru}

Berdasarkan hasil analisis regresi yang dilakukan diketahui bahwa pengawasan yang dilakukan berpengaruh terhadap kinerja guru. Besarnya koefisien pengaruh langsung pengawasan terhadap kinerja guru bertanda positif (0.281). Hal ini mengindikasikan bahwa pengaruh pengawasan terhadap kinerja guru adalah positif yakni memiliki arah yang sama. Dengan demikian semakin tinggi pengawasan yang dilakukan seorang guru maka akan semakin 
meningkatkan kinerja guru tersebut. Demikian pula semakin menurunnya intensitas pengawasan oleh guru akan mebuat kinerjanya semakin rendah.

Hasil analisis ini sejalan dengan temuan Wibowo (2009) yang membuktikan bahwa kegiatan supervisi pada kegiatan pembelajaran memberikan pengaruh nyata terhadap peningkatan kualitas pembelajaran yang dilakukan oleh guru. Supervisi yang dimaksud dalam temuan Wibowo tersebut merupakan kegiatan pembinaan dan pengawasan terhadap aktifitas aktifitas pembelajaran yang dilakukan di sekolah sehubungan dengan upaya memaksimalkan kualitas guru dalam menjalankan aktifitasnya.

Berdasarkan hasil analisis deskriptif diketahui bahwa tingkat kegiatan pengawasan oleh guru-guru SMP Negeri di Kecamatan Mapilli berada pada kategori tinggi. Namun seperti beberapa variabel yang dibahas sebelumnya, bahwa terdapat beberapa kekurangan yang ditemui di dalam proses penelitian. Beberapa kekurangan yang dimaksud diantaranya adalah terdapat beberapa guru yang masih perlu mendapat perhatian lebih oleh karen masih perlu peningkatan kaitannya dengan kegiatan pengawan feedforward. Hal tersebut diidentifikasi karena masih terdapat beberapa guru yang kurang mengoptimalkan perhatiannya untuk meninjau perangkat pembelajaran yang akan digunakan dalam kegiatan pembelajaran di kelas. Selain itu pada tinjauan pelaksanaan kegiatan feedback ditemukan bahwa sebagian guru hanya lebih memaksimalkan pada rencana pengajaran yang akan dilakukan selanjutnya, namun kurang memperhatikan hasil dari rencana pengajaran yang telah dilakukan sebelumnya.

Analisis hubungan antara vaiabel pengawasan terhadap indikatorindikatornya membuktikan adanya hubungan yang kuat, baik itu pengawasan feedforward atau pengawasan pendahuluan, pengawasan pada saat kegiatan berlangsung atau pengawasan concurrent dan pengawasan feedback atau kegiatan pengawasan akhir kegiatan.

Berdasarkan beberapa uraian tersebut maka dapat dikatakan bahwa variabel pengawasan menjadi salah satu unsur penting dalam meningkatkan kualitas pelaksanaan kegiatan pembelajaran oleh guru yang pada akhirnya akan meningkatkan kinerja guru tersebut.

\section{Pengaruh Profesionalisme, Motivasi dan Pengawasan terhadap Kinerja Guru}

Kinerja guru merupakan suatu penilaian akan kemampuan guru dalam mencapai tujuan pembelajaran, yang dilihat dari penampilannya dalam melakukan proses belajar mengajar. Hasil analisis deskriptif yang telah dilakukan membuktikan bahwa Guru SMP Negeri di Kecamatan Mapilli memiliki kinerja yang tinggi dan memiliki hubungan yang sangat kuat dengan tingakt profesionalisme, motivasi yang dimiliki serta kegiatan pengawasan yang dilakukan.

Adanya hubungan yang sangat kuat diantara keempat variabel tersebut dapat diidentifikasi oleh karena keempat variabel tersebut secara paralel memiliki 
tingkat kecenderungan yang tinggi dan saling berhubungan antara variabel satu dengan variabel yang lainnya. Hal ini mengisyaratkan bahwa menurun atau meningkatnya kualitas pada salah satu variabel akan mempengaruhi variabel lainnya.

Hasil analisis membuktikan bahwa secara simultan variabel profesionalisme, motivasi dan pengawasan berpengaruh signifikan terhadap perubahan variabel kinerja guru yang ditunjukkan oleh perolehan hasil uji $\mathrm{F}$ (probabiliti $\mathrm{F}<0.05$ ). Sementara itu mengacu pada perolehan nilai $R$-Square sebesar 0.892 menunjukkan bahwa proporsi pengaruh profesionalisme, motivasi dan pengawasan terhadap kinerja guru adalah $89,2 \%$. Hal ini berarti tingkat kecenderungan profesionalisme, motivasi dan tingginya intensitas pengawasan yang dilakukan oleh Guru SMP Negeri di Kecamatan Mapilli memiliki proporsi pengaruh terhadap kinerja guru sebesar $89,2 \%$ sedangkan $10.8 \%$ sisanya dipengaruhi oleh variabel lain yang tidak terdapat didalam model regresi linear.

\section{SIMPULAN}

Berdasarkan hasil analisis data statistik dapat ditarik kesimpulan bahwa

Tingkat profesionalisme, tingkat motivasi, dan tingkat pengawasan serta tingkat kinerja Guru SMP Negeri di Kecamatan Mapilli secara keseluruhan berada pada kategori tinggi. Tingkat profesionalisme berpengaruh postitif terhadap peningkatan kinerja guru. Hal ini mengindikasikan bahwa tinggi rendahnya tingkat profesionalisme yang dimiliki searah dengan tingkat kinerja yang dihasilkan. Artinya, semakin tinggi tingkat profesionalisme guru maka semakin tinggi pula kinerja guru yang dihasilkan. Sebaliknya, semakin rendah tingkat profesionalisme guru yang dimiliki menyebabkan semakin rendahnya tingkat kinerja guru yang dihasilkan. Tingkat motivasi berpengaruh postitif terhadap peningkatan kinerja guru. Hal ini mengindikasikan bahwa tinggi rendahnya tingkat motivasi yang dimiliki searah dengan tingkat kinerja yang dihasilkan. Artinya, semakin tinggi tingkat motivasi guru maka semakin tinggi pula kinerja guru yang dihasilkan. Sebaliknya, semakin rendah tingkat motivasi guru yang dimiliki menyebabkan semakin rendahnya tingkat kinerja guru yang dihasilkan. Tingkat pengawasan berpengaruh postitif terhadap peningkatan kinerja guru. Hal ini mengindikasikan bahwa tinggi rendahnya intensitas pengawasan yang dilakukan searah dengan tingkat kinerja yang dihasilkan. Artinya, semakin tinggi intensitas pengawasan guru maka semakin tinggi pula kinerja guru yang dihasilkan. Sebaliknya, semakin rendah intensitas pengawasan guru menyebabkan semakin rendahnya tingkat kinerja guru yang dihasilkan. Profesionalisme, motivasi dan pengawasan secara simultan berpengaruh terhadap peningkatan kinerja guru. Adapun besaran kontribusi profesionalisme, motivasi dan pengawasan terhadap perubahan kinerja guru adalah sebesar 89.2\%. Hal ini berarti ketiga variabel independen yakni profesionalisme, motivasi dan 
pengawasan memiliki pengaruh yang sangat tinggi terhadap tinggi rendahnya kinerja yang dihasilkan oleh guru.

\section{SARAN DAN REKOMENDASI}

Berdasarkan kesimpulan atas hasil penelitian ini disarankan kepada praktisi pendidikan, dalam hal ini dikhususkan kepada Guru SMP Negeri di Kecamatan Mapilli untuk: (1) melakukan aktifitas penunjang kegiatan pembelajaran seperti mengembangkan metode-metode baru yang relevan dalam melaksanakan aktiftas pengajaran di sekolah sehingga memberi peluang kepada peserta didik untuk semakin meingkatkan hasil belajarnya yang pada akhirnya akan mengahasilkan kinerja yang baik sebagai praktisi pendidikan, (2) mengembangkan pengetahuan terhadap materi yang diajarkan serta keterampilan mengajar sehingga dapat mengoptimalkan kualitas pembelajaran yang dihasilkan dan rasa percaya diri dalam mengahadapi berbagai situasi yang berbeda pada saat melaksanakan proses pengajaran. Kepada peneliti disarankan untuk melakukan penelitian lebih lanjut tentang upaya peningkatan kinerja guru melibatkan: (1) variabel terikat lainnya seperti: metode atau media yang digunakan dan (2) kriteria kinerja guru yang berkualitas seperti: tinjauan pada hasil belajar peserta didik.

\section{DAFTAR PUSTAKA}

Arikunto, Suharsimi . 2006. Prosedur Penelitian Suatu Pendekatan Praktik. Jakarta:Rineka Cipta

Hasibuan, Malayu SP. 2005. Manajemen Sumber Daya Manusia, Edisi Revisi. Bumi Aksara, Jakarta.

Mulyasa, E. (2009). Menjadi Guru Profesional. Bandung: PT. Remaja Rosdakarya.

Permadi, D. dan Arifin, D. (2010). The Smiling Teacher: Perubahan Motivasi dan Sikap dalam Mengajar. Bandung: CV. Nuansa Aulia.

Sugiyono. 2012. Metode Penelitian Bisnis. Bandung : Alfabeta

Pratiwi, S. D. (2013). Pengaruh motivasi kerja, kepuasan kerja, kepemimpinan kepala sekolah menurut persepsi guru, dan iklim sekolah terhadap kinerja guru ekonomi SMP Negeri di Kabupaten Wonogiri. S2 Pendidikan Ekonomi, $2(1)$.

Wibowo 2009. Pengaruh supervisi kepala sekolah dan kompetensi pedagogik guru terhadap kinerja guru terhadap kinerja guru SD negeri kec.kersana kab.brebes 